\title{
The Application of Drones in Healthcare and Health-Related Services in North America: A Scoping Review
}

\author{
Bradley Hiebert ${ }^{1, *(\mathbb{D})}$, Elysée Nouvet ${ }^{2}$, Vyshnave Jeyabalan $^{3}$ and Lorie Donelle ${ }^{1}$ \\ 1 Arthur Labatt Family School of Nursing, FIMS \& Nursing Building, Western University, \\ London, ON N6A 5B9, Canada; ldonelle@uwo.ca \\ 2 School of Health Studies, Labatt Health Sciences Building, Western University, \\ London, ON N6A 3K7, Canada; enouvet@uwo.ca \\ 3 Department of Health Information Sciences, Faculty of Information and Media Studies, \\ FIMS \& Nursing Building, Western University, London, ON N6A 3K7, Canada; vjeyabal@uwo.ca \\ * Correspondence: bhieber@uwo.ca
}

Received: 10 June 2020; Accepted: 2 July 2020; Published: 4 July 2020

check for updates

\begin{abstract}
Using drone aircraft to deliver healthcare and other health-related services is a relatively new application of this technology in North America. For health service providers, drones represent a feasible means to increase their efficiency and ability to provide services to individuals, especially those in difficult to reach locations. This paper presents the results of a scoping review of the research literature to determine how drones are used for healthcare and health-related services in North America, and how such applications account for human operating and machine design factors. Data were collected from PubMed, CINAHL, Scopus, Web of Science, and IEEE Xplore using a block search protocol that combined 13 synonyms for "drone" and eight broad terms capturing healthcare and health-related services. Four-thousand-six-hundred-and-sixty-five documents were retrieved, and following a title, abstract, and full-text screening procedure completed by all authors, 29 documents were retained for analysis through an inductive coding process. Overall, findings indicate that drones may represent a financially feasible means to promote healthcare and health-related service accessibility for those in difficult-to-reach areas; however, further work is required to fully understand the costs to healthcare organizations and the communities they serve.
\end{abstract}

Keywords: healthcare; health services; health applications; Canada; United States; community engagement; drones

\section{Introduction}

Drones represent exciting potential for increasing the capacities and efficiency of healthcare systems. In this paper, drones are understood as any unmanned aircraft, including fixed-wing and single or multi-copter, that are remotely piloted. Often characterized as a "leapfrog" technology [1,2], drones are widely lauded for their capacity to circumvent many of the challenges to healthcare delivery that previously impeded access to healthcare services, particularly in isolated or hard to reach areas. Drones are poised to speed up the retrieval and delivery of life-saving products such as vaccines or blood packs [3-9], and increase access to a range of healthcare supplies, expertise, and procedures in hard-to-reach rural and remote communities $[7,8,10,11]$. Several studies have been conducted worldwide contributing to the limited evidence of drones' potential to meet healthcare-related needs. Sub-Saharan Africa has been host to a particularly high concentration of the world's pilot programs for the use of drones to support national healthcare priorities and programs [7]. 
Application of drone technology for healthcare purposes in North America is still in its infancy [3]. Much of the existing scholarly literature in North America is theoretical and focuses on how applications of drone technology could be structured within healthcare. This paper sets out to map actual applications of drone technology for healthcare and other health-related purposes in the North American context. More specifically, the purpose of this scoping review is to: (1) describe how drones are being used for healthcare purposes in North America; (2) synthesize the knowledge base being developed in published descriptions of these applications; and (3) identify gaps within this knowledge base. In doing so, this paper provides a North American overview of the use of drones for healthcare and health-related purposes and identifies priorities for future research.

\section{A Note on the North American Focus}

North America denotes here Canada, the United States, and Mexico. Uses and implications for healthcare of drones cannot be described in universal terms. Different contexts harbour different healthcare delivery challenges to which drones may or may not provide an answer. Different populations harbour different health needs. Different health challenges, policy priorities, and regulatory environments will attract different interests, players, and partnerships into the "drones for healthcare" landscape. All of these factors can in turn generate and support diverse ideas and approaches to the integration of this new technology within healthcare delivery systems. While North America includes diverse nations, cultures, and languages, it also shares a number of characteristics that could be seen to set it apart from other regions, such as the European Union. This includes vast regions of each country that are primarily rural, distances between major urban centres that often extend hundreds of kilometers, and hard-to-access (fly in or ice road only) communities-mostly Indigenous—with limited access to healthcare. Many early adopters of drone technology in North America have published peer-reviewed accounts of their efforts and reflections. Towards advancing current and imagined potential uses of drone technology within the North American context, it is important to take stock of what has been done, highlighted as significant, and identified in terms of future application for this technology. While focused on North America, we anticipate this review to be of relevance to all interested in deepening understanding of this emerging technology for healthcare delivery.

\section{Methods}

This study followed Arksey and O'Malley's [12] framework to conduct a scoping review of research literature to determine how drones are used for healthcare and health-related services in North America. Since the use of drones for healthcare and health-related purposes is a relatively recent application of this technology in North America, a scoping review methodology was selected since this approach facilitates the identification of knowledge gaps and future research and policy development [12].

\section{Document Selection}

A literature search was conducted and completed in May 2020 of online databases believed to index health- and/or drone-related research in North America, including PubMed, CINAHL, Scopus, Web of Science, and IEEE Xplore. Since research into the application of drones for health-related purposes in North America is in its infancy, no timeframe constraints were placed on the literature search strategy.

Following consultation with an academic research librarian, a two-block search strategy was created to maximize the breadth of the initial literature search. Block one contained drone technology nomenclature. Block two contained broad healthcare nomenclature. For a full list of key terms used in each block, see Table 1. Note that block one contains the full names instead of popular acronyms used for drone technologies as any articles that included the acronym would first include the full name, which would be identified in the database search. Full names and accompanying acronyms include unmanned aerial vehicle (UAV), unmanned aerial system (UAS), remotely piloted vehicle (RPV), 
remotely piloted aircraft (RPA), and remotely operated vehicle (ROV). The search was constructed in three steps: (1) the Boolean operator "OR" was used to connect all terms in block 1; (2) the Boolean operator "OR" was used to connect all terms in block (2); and (3) the Boolean operator "AND" was used to connect all terms in block 1 with all terms in block 2 to ensure all documents retrieved included both drone and health nomenclature.

Table 1. Terms used in two-block initial document search strategy to identify articles with a focus on the use of drones for healthcare or health-related applications.

\begin{tabular}{|c|c|c|}
\hline & Block 1-Drone Nomenclature & Block 2-Health Nomenclature \\
\hline Terms & $\begin{array}{c}\text { drone } \\
\text { drones } \\
\text { unmanned aerial vehicle } \\
\text { unmanned aerial vehicles } \\
\text { unmanned aerial system } \\
\text { unmanned aerial systems } \\
\text { remotely piloted vehicle } \\
\text { remotely piloted vehicles } \\
\text { remotely piloted aircraft } \\
\text { remotely piloted aircraft system } \\
\text { remotely piloted aircraft systems } \\
\text { remotely operated vehicle } \\
\text { remotely operated vehicles }\end{array}$ & $\begin{array}{c}\text { Health } \\
\text { Well-being } \\
\text { Well being } \\
\text { Healthcare } \\
\text { Health care } \\
\text { Public health } \\
\text { Medicine } \\
\text { Medical }\end{array}$ \\
\hline
\end{tabular}

Initial search results yielded 4655 documents from five databases. Following the removal of 1044 duplicates, 3611 unique documents were retained for title and abstract screening. Documents were retained for full-text review if they met the following inclusion criteria during title and abstract screening:

- Title or abstract indicates focus on healthcare, medicine, public health, and/or human population health application;

- Authors explicitly state North American (i.e., Canada, United States, or Mexico) context;

- Document was peer-reviewed; and

- Document was written in English.

Two authors conducted the title and abstract review. At this stage, documents were excluded from analysis if any of the following criteria were met: there was no indication of a focus on healthcare, medicine, public health, and/or human population health applications; North American context was not stated; the document was not peer-reviewed; or the document was not written in English. Both authors conducting the title and abstract review reviewed every document, and when there was a discrepancy regarding whether to include a document, a third and fourth author were consulted. Following title and abstract reviews, two authors conducted full-text review of each remaining document to ensure that: (1) the document focused on a North American context, (2) the document focused specifically on the design or application of drones to address a healthcare or health-related issue.

A total of 180 documents were included for full-text review following the title and abstract review stage, with the two reviewing authors agreeing on $92 \%(\mathrm{~N}=158)$. The majority of documents excluded during full-text review did not have an explicit focus on the application of drones for healthcare or health-related purposes, but rather discussed the technical theory behind the mechanical design of drones for such applications. Figure 1 provides a detailed outline of the document inclusion process in this study. 


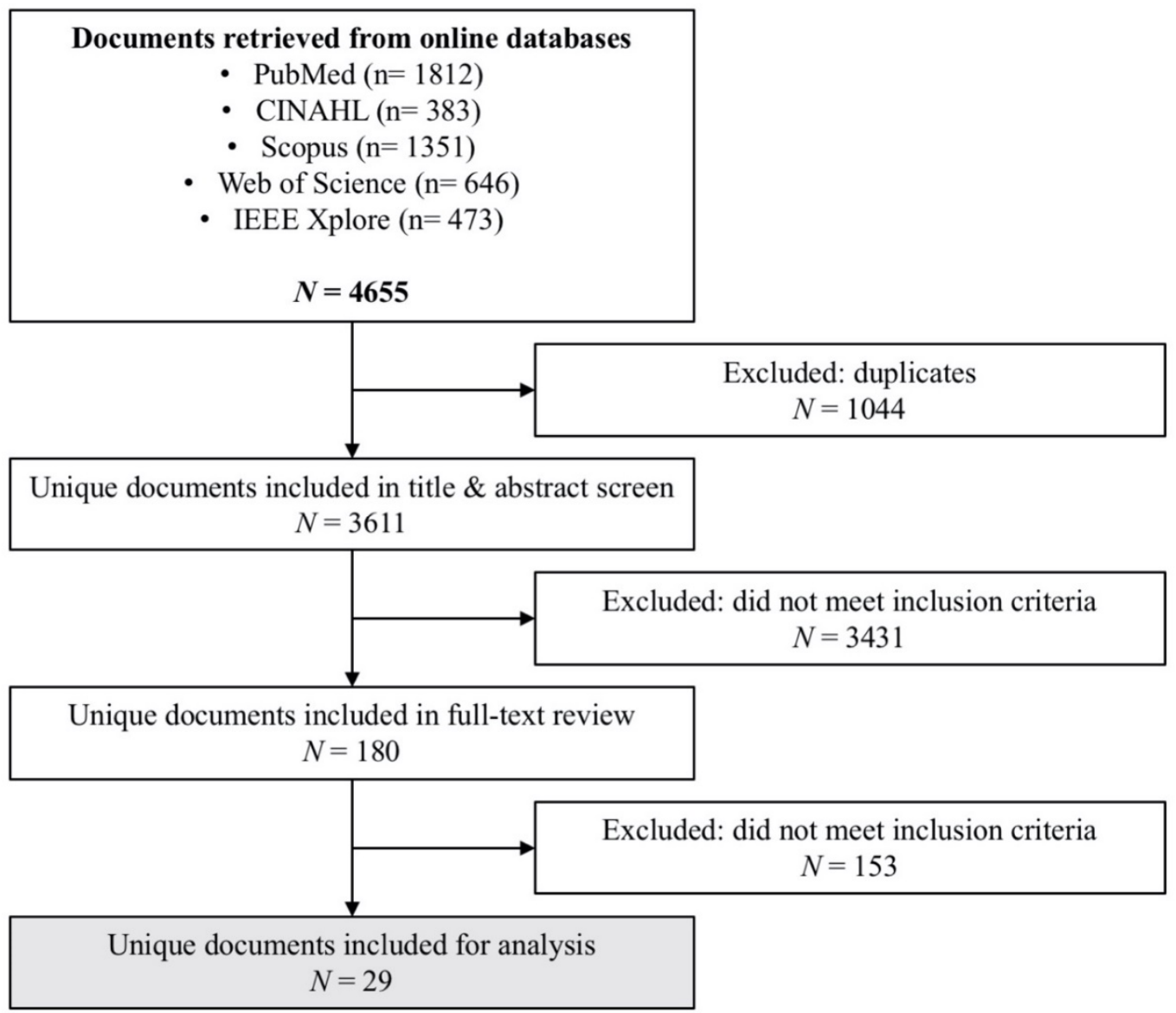

Figure 1. Document inclusion and exclusion process.

\section{Data Analysis}

Each article in this sample was subjected to conventional content analysis using inductive coding [13], which allowed codes and dominant coding categories to emerge naturally from the data [13]. Data analysis and organization was conducted using $\mathrm{N}^{*}$ Vivo 12 [14], and was completed by all authors in cooperation. To harmonize coding terminology, three authors began the data analysis by independently coding the same subset of four articles. All four authors discussed the initial codes that emerged from this initial subset to arrive at a shared understanding of the inductive coding process. Two authors then completed inductive coding for the entire sample and then met to discuss codes that had emerged and to align code terminology with each other once all articles had been coded. Finally, all four authors convened to discuss the inductive codes derived from the data to maximize analytic insight into this data set. Five dominant categories emerged from this sample, all of which are discussed in detail in the following section.

\section{Results}

Twenty-nine documents were retained for analysis that focused specifically on the application of drones for healthcare or health-related application in North America. All documents were published in 2007 or later, with $24(83 \%)$ published since 2017. Eight documents $(28 \%)$ described studies conducted in Canada, while 21 documents (72\%) described studies conducted in The United States. No documents that met inclusion criteria were based in Mexico. Twenty-five documents (86\%) focused on the technological aspects of using drones for health-related purposes, such as how to design the payload compartment to safely transport medications and biological materials or how to effectively create a drone network to meet the needs of rural communities. Four documents 
(14\%) focused on the human aspect of using drones for health-related purposes, such as the ability of human participants to accurately identify items through a drone-mounted camera or interact with drones in various health-related settings. Two documents $(7 \%)$ were literature reviews that included details about both technology- and human-focused studies. Twenty-eight studies examined the use of drones outdoors, while one study [15] did not specify if the health-related application (guiding blind runners on a running track) occurred indoors or outdoors. No studies explicitly examined the applications of drones in indoor settings, such as hospitals or nursing homes. A total of 12 different population segments were targeted by these studies, including: emergency first responders $(\mathrm{N}=11)$, biomedica supply transporters $(\mathrm{N}=10$ documents), rural and remote populations $(\mathrm{N}=5)$, firefighters $(\mathrm{N}=3)$, urban populations $(\mathrm{N}=2)$, Indigenous populations $(\mathrm{N}=1)$, coal miners $(\mathrm{N}=1)$, critically-ill patients $(\mathrm{N}=1)$, elderly populations in general $(\mathrm{N}=1)$, military medical personnel $(\mathrm{N}=1)$, telemedicine providers $(\mathrm{N}=1)$, and blind individuals $(\mathrm{N}=1)$. See Table 2 for details regarding each included article's characteristics.

Study authors included representation from a variety of disciplines, including: computer engineering, software engineering, computer science, nursing, public health, medicine, paramedicine, aviation, kinesiology, and pathology. Eight studies reported zero authors with a healthcare or health-related appointment [16-21]. This has important implications for the development of healthcare drone applications, as such innovation is being driven by those in computer and software engineering, computer science, and aviation, without significant input from healthcare researchers or professionals. External partners and funding sources are not always clear, but organizations involved in these studies include private industry partners such as drone manufacturers, national organizations related to biomedical supply transport and aviation, local medical organizations such as hospitals, and local community groups such as town councils.

This sample of articles can be described by the five overarching codes established during inductive content analysis: (1) health applications, (2) benefits and costs of drones, (3) factors influencing use and performance, (4) sociocultural context, and (5) author-identified next steps.

\subsection{Health Applications}

Authors of each of the 29 articles included in this review examined how drones were utilized for a specific health or health-related issue. Using drones to deliver medical supplies and treatments (e.g., gauze, testing kits, and medications) was the most common $(\mathrm{N}=11)$ health application $[3,15,20,22-31]$. Environmental monitoring (e.g., wildfire, landslide, and air quality monitoring) was the second most $(\mathrm{N}=8)$ examined intervention $[16,18,19,21,25,26,31-33]$, and using drones to deliver automated external defibrillators (AEDs) for cardiac emergencies was the third most $(\mathrm{N}=8)$ examined intervention $[4,17,22,30,33-35]$. Less frequently reported in the research literature was the use of drones to transport biological samples (e.g., blood, plasma, organs, and other tissues) $(\mathrm{N}=6)[20,22,27,36-38]$, to facilitate search and rescue operations $(N=4)[29,32,39,40]$, for emergency service delivery $(\mathrm{N}=3)[24,25,28]$, to support first responder safety $(\mathrm{N}=3)[24,25,29]$, and for remote medical support $(\mathrm{N}=2)[17,22]$. 
Table 2. Documents included in analysis of drone use for healthcare and health-related applications in North America.

\begin{tabular}{|c|c|c|c|c|c|c|}
\hline Article Author & Article Title & Year & Country of Study & $\begin{array}{c}\text { Human-or } \\
\text { Technology-Focused }\end{array}$ & $\begin{array}{l}\text { Indoor or Outdoor } \\
\text { Application }\end{array}$ & $\begin{array}{c}\text { Targeted Population } \\
\text { Segments }\end{array}$ \\
\hline $\begin{array}{c}\text { Al-Rawabdeh, A., } \\
\text { Moussa, A., Foroutan, M., } \\
\text { El-Sheimy, N., \& Habib, A. }\end{array}$ & $\begin{array}{c}\text { Time series UAV } \\
\text { image-based point clouds for } \\
\text { landslide progression } \\
\text { evaluation applications }\end{array}$ & 2017 & Canada & Technology & Outdoor & Urban populations \\
\hline $\begin{array}{l}\text { Al-Zayer, M., Tregillus, S., } \\
\text { Bhandari, J., Feil-Seifer, D., } \\
\text { \& Folmer, E. }\end{array}$ & $\begin{array}{l}\text { Exploring the use of a drone } \\
\text { to guide a blind runner }\end{array}$ & 2016 & United States & Human & Not specified & Blind individuals \\
\hline $\begin{array}{l}\text { Amukele, T.K., Sokoll, L.J., } \\
\text { Pepper, D., Howard, D.P., \& } \\
\text { Street, J. }\end{array}$ & $\begin{array}{l}\text { Can unmanned aerial } \\
\text { systems (Drones) be used for } \\
\text { the routine transport of } \\
\text { chemistry, hematology, and } \\
\text { coagulation laboratory } \\
\text { specimens? }\end{array}$ & 2015 & United States & Technology & Outdoor & $\begin{array}{l}\text { Biomedical supply } \\
\text { transport }\end{array}$ \\
\hline $\begin{array}{c}\text { Amukele, T.K., Street, J., } \\
\text { Carroll, K., Miller, H., \& } \\
\text { Zhang, S.X. }\end{array}$ & $\begin{array}{l}\text { Drone transport of microbes } \\
\text { in blood and sputum } \\
\text { laboratory specimens. }\end{array}$ & 2016 & United States & Technology & Outdoor & $\begin{array}{l}\text { Biomedical supply } \\
\text { transport }\end{array}$ \\
\hline $\begin{array}{c}\text { Amukele, T.K., } \\
\text { Hernandez, J., Snozek, C.L., } \\
\text { Wyatt, R.G., Douglas, M., } \\
\text { Amini, R., \& Street, J. }\end{array}$ & $\begin{array}{c}\text { Drone Transport of } \\
\text { Chemistry and Hematology } \\
\text { Samples over Long } \\
\text { Distances. }\end{array}$ & 2017 & United States & Technology & Outdoor & $\begin{array}{l}\text { Biomedical supply } \\
\text { transport }\end{array}$ \\
\hline Balasingam, $\mathrm{M}$. & $\begin{array}{c}\text { Drones in medicine-the rise } \\
\text { of the machines }\end{array}$ & 2017 & United States & Technology & Outdoor & $\begin{array}{c}\text { Biomedical supply } \\
\text { transport; emergency } \\
\text { first responders; } \\
\text { telemedicine } \\
\text { providers; elderly } \\
\text { individuals }\end{array}$ \\
\hline $\begin{array}{l}\text { Bogle, B., Rosamond, W., } \\
\text { Synder, K.T., \& } \\
\text { Zègre-Hemsey, J.K. }\end{array}$ & $\begin{array}{l}\text { The case for drone-assisted } \\
\text { emergency response to } \\
\text { cardiac arrest }\end{array}$ & 2019 & United States & Technology & Outdoor & $\begin{array}{l}\text { Emergency first } \\
\text { responders }\end{array}$ \\
\hline
\end{tabular}


Table 2. Cont.

\begin{tabular}{|c|c|c|c|c|c|c|}
\hline Article Author & Article Title & Year & Country of Study & $\begin{array}{c}\text { Human-or } \\
\text { Technology-Focused }\end{array}$ & $\begin{array}{c}\text { Indoor or Outdoor } \\
\text { Application }\end{array}$ & $\begin{array}{c}\text { Targeted Population } \\
\text { Segments }\end{array}$ \\
\hline $\begin{array}{l}\text { Boutilier, J.J., Brooks, S.C., } \\
\text { Janmohamed, A., Byers, A., } \\
\text { Buick, J.E., Zhan, C., ... } \\
\text { Chan, C.Y. }\end{array}$ & $\begin{array}{l}\text { Optimizing a Drone Network } \\
\text { to Deliver Automated } \\
\text { External Defibrillators. }\end{array}$ & 2017 & Canada & Technology & Outdoor & $\begin{array}{l}\text { Emergency first } \\
\text { responders; urban } \\
\text { populations }\end{array}$ \\
\hline $\begin{array}{l}\text { Braun, J., Gertz., S.D., } \\
\text { Furer, A., Bader, T., } \\
\text { Frenkel, H., Chen, J., } \\
\text { Glassberg, E., \& } \\
\text { Nachman, D. }\end{array}$ & $\begin{array}{l}\text { The promising future of } \\
\text { drones in prehospital medical } \\
\text { care and its application to } \\
\text { battlefield medicine }\end{array}$ & 2019 & United States & Technology & Outdoor & Military healthcare \\
\hline $\begin{array}{l}\text { Cardil, A., Monedero, S., } \\
\text { Ramírez, J., \& Silva, C.A. }\end{array}$ & $\begin{array}{l}\text { Assessing and reinitializing } \\
\text { wildland fire simulations } \\
\text { through satellite active fire } \\
\text { data. }\end{array}$ & 2018 & United States & Technology & Outdoor & Firefighters \\
\hline $\begin{array}{l}\text { Carrillo-Larco, R.M., } \\
\text { Moscoso-Porras, M., } \\
\text { Taype-Rondan, A., } \\
\text { Ruiz-Alejos, A., \& } \\
\text { Bernabe-Ortiz, A. }\end{array}$ & $\begin{array}{l}\text { The use of unmanned aerial } \\
\text { vehicles for health purposes: } \\
\text { a systematic review of } \\
\text { experimental studies. }\end{array}$ & 2018 & United States & Human \& Technology & Outdoor & $\begin{array}{l}\text { Emergency first } \\
\text { responders; } \\
\text { Biomedical supply } \\
\text { transport }\end{array}$ \\
\hline $\begin{array}{c}\text { Clark, D.G., Ford, J.D., \& } \\
\text { Tabish, T. }\end{array}$ & $\begin{array}{l}\text { What role can unmanned } \\
\text { aerial vehicles play in } \\
\text { emergency response in the } \\
\text { Arctic: A case study from } \\
\text { Canada. }\end{array}$ & 2018 & Canada & Human & Outdoor & $\begin{array}{l}\text { Remote populations } \\
\text { Indigenous } \\
\text { populations }\end{array}$ \\
\hline Cohen, J. & $\begin{array}{l}\text { Natural disasters: Drone spy } \\
\text { plane helps fight California } \\
\text { fires. }\end{array}$ & 2007 & United States & Technology & Outdoor & Firefighters \\
\hline $\begin{array}{c}\text { Dayananda, K.R., Gomes, } \\
\text { R., \& Straub, J. }\end{array}$ & $\begin{array}{c}\text { An interconnected } \\
\text { architecture for an emergency } \\
\text { medical response unmanned } \\
\text { aerial system. }\end{array}$ & 2017 & United States & Technology & Outdoor & $\begin{array}{l}\text { Emergency first } \\
\text { responders }\end{array}$ \\
\hline
\end{tabular}


Table 2. Cont.

\begin{tabular}{|c|c|c|c|c|c|c|}
\hline Article Author & Article Title & Year & Country of Study & $\begin{array}{c}\text { Human-or } \\
\text { Technology-Focused }\end{array}$ & $\begin{array}{c}\text { Indoor or Outdoor } \\
\text { Application }\end{array}$ & $\begin{array}{c}\text { Targeted Population } \\
\text { Segments }\end{array}$ \\
\hline $\begin{array}{l}\text { Dunnington, L., \& } \\
\text { Nakagawa, M. }\end{array}$ & $\begin{array}{l}\text { Fast and safe gas detection } \\
\text { from underground coal fire } \\
\text { by drone fly over. }\end{array}$ & 2017 & United States & Technology & Outdoor & $\begin{array}{l}\text { Coal miners; } \\
\text { firefighters }\end{array}$ \\
\hline Francisco, M. & $\begin{array}{c}\text { Organ delivery by } 1000 \\
\text { drones. }\end{array}$ & 2016 & United States & Technology & Outdoor & $\begin{array}{c}\text { Biomedical supply } \\
\text { transport }\end{array}$ \\
\hline Glauser, W. & $\begin{array}{l}\text { Blood-delivering drones } \\
\text { saving lives in Africa and } \\
\text { maybe soon in Canada. }\end{array}$ & 2018 & Canada & Technology & Outdoor & $\begin{array}{l}\text { Biomedical supply } \\
\text { transport; rural } \\
\text { populations }\end{array}$ \\
\hline $\begin{array}{c}\text { Homier, V., } \\
\text { de Champlain, F., } \\
\text { Nolan, M., \& Fleet, R. }\end{array}$ & $\begin{array}{l}\text { Identification of swimmers in } \\
\text { distress using unmanned } \\
\text { aerial vehicles: Experience at } \\
\text { the Mont-Tremblant } \\
\text { IRONMAN triathlon }\end{array}$ & 2020 & Canada & Technology & Outdoor & $\begin{array}{l}\text { Emergency first } \\
\text { responders }\end{array}$ \\
\hline $\begin{array}{c}\text { Jain, T., Sibley, A., } \\
\text { Stryhn, H., \& Hubloue, I. }\end{array}$ & $\begin{array}{l}\text { Comparison of unmanned } \\
\text { aerial vehicle } \\
\text { technology-assisted triage } \\
\text { versus standard practice in } \\
\text { triaging casualties by } \\
\text { paramedic students in a } \\
\text { mass-casualty incident } \\
\text { scenario. }\end{array}$ & 2018 & Canada & Human & Outdoor & $\begin{array}{l}\text { Emergency first } \\
\text { responders }\end{array}$ \\
\hline $\begin{array}{c}\text { Jain, T., Sibley, A., } \\
\text { Stryhn, H., \& Hubloue, I. }\end{array}$ & $\begin{array}{l}\text { Comparison of Unmanned } \\
\text { Aerial Vehicle Technology } \\
\text { Versus Standard Practice in } \\
\text { Identification of Hazards at a } \\
\text { Mass Casualty Incident } \\
\text { Scenario by Primary Care } \\
\text { Paramedic Students. }\end{array}$ & 2018 & Canada & Human & Outdoor & $\begin{array}{l}\text { Emergency first } \\
\text { responders }\end{array}$ \\
\hline $\begin{array}{l}\text { Jalal, A.H., Umasankar, Y., } \\
\text { Christopher, F., Pretto, E.A., } \\
\text { \& Bhansali, S. }\end{array}$ & $\begin{array}{l}\text { A model for safe transport of } \\
\text { critical patients in unmanned } \\
\text { drones with a 'watch' style } \\
\text { continuous anesthesia sensor. }\end{array}$ & 2018 & United States & Technology & Outdoor & Critically-ill patients \\
\hline
\end{tabular}


Table 2. Cont.

\begin{tabular}{|c|c|c|c|c|c|c|}
\hline Article Author & Article Title & Year & Country of Study & $\begin{array}{c}\text { Human-or } \\
\text { Technology-Focused }\end{array}$ & $\begin{array}{c}\text { Indoor or Outdoor } \\
\text { Application }\end{array}$ & $\begin{array}{c}\text { Targeted Population } \\
\text { Segments }\end{array}$ \\
\hline $\begin{array}{l}\text { Kim, S.J., Lim, G.J., Cho, J., } \\
\text { \& Côté, M.J. }\end{array}$ & $\begin{array}{l}\text { Drone-Aided Healthcare } \\
\text { Services for Patients with } \\
\text { Chronic Diseases in Rural } \\
\text { Areas. }\end{array}$ & 2017 & United States & Technology & Outdoor & $\begin{array}{l}\text { Rural populations; } \\
\text { healthcare personne }\end{array}$ \\
\hline $\begin{array}{c}\text { Canadian Agency for } \\
\text { Drugs and Technology in } \\
\text { Health. }\end{array}$ & $\begin{array}{l}\text { Focus on: Drone applications } \\
\text { in health care }\end{array}$ & 2018 & Canada & Technology & Outdoor & Rural populations \\
\hline $\begin{array}{l}\text { Lin, C.A., Shah, K., } \\
\text { Mauntel, L.C.C., \& } \\
\text { Shah, S.A. }\end{array}$ & $\begin{array}{c}\text { Drone delivery of } \\
\text { Medications: Review of the } \\
\text { landscape and legal } \\
\text { considerations. }\end{array}$ & 2018 & United States & Human \& Technology & Outdoor & $\begin{array}{l}\text { Biomedical supply } \\
\text { transport }\end{array}$ \\
\hline $\begin{array}{l}\text { Mark, D.B., Hansen, S.M., } \\
\text { Starks, M.L., \& } \\
\text { Cummings, M.L. }\end{array}$ & $\begin{array}{c}\text { Drone-Based Automatic } \\
\text { External Defibrillators for } \\
\text { Sudden Death?: Do We Need } \\
\text { More Courage or More } \\
\text { Serenity? }\end{array}$ & 2017 & United States & Technology & Outdoor & $\begin{array}{l}\text { Emergency first } \\
\text { responders; }\end{array}$ \\
\hline $\begin{array}{l}\text { Scalea, J.R., Restaino, S., } \\
\text { Scassero, M., Blankenship, } \\
\text { G., Bartlett, S.T., \& } \\
\text { Wereley, N. }\end{array}$ & $\begin{array}{l}\text { An initial investigation of } \\
\text { unmanned aircraft systems } \\
\text { (UAS) and real-time organ } \\
\text { status measurement for } \\
\text { transporting human organs. }\end{array}$ & 2018 & United States & Technology & Outdoor & $\begin{array}{l}\text { Biomedical supply } \\
\text { transport }\end{array}$ \\
\hline $\begin{array}{l}\text { Scalea, J.R., Restaino, S., } \\
\text { Scassero, M., Bartlett, S.T., } \\
\text { \& Wereley, N. }\end{array}$ & $\begin{array}{c}\text { The final frontier? Exploring } \\
\text { organ transportation by } \\
\text { drone. }\end{array}$ & 2019 & United States & Technology & Outdoor & $\begin{array}{l}\text { Biomedical supply } \\
\text { transport }\end{array}$ \\
\hline Van Tilburg, C. & $\begin{array}{c}\text { First Report of Using } \\
\text { Portable Unmanned Aircraft } \\
\text { Systems (Drones) for Search } \\
\text { and Rescue. }\end{array}$ & 2017 & United States & Technology & Outdoor & $\begin{array}{l}\text { Emergency first } \\
\text { responders; remote } \\
\text { populations }\end{array}$ \\
\hline $\begin{array}{c}\text { Zègre-Hemsey, J.K., } \\
\text { Bogle, B., } \\
\text { Cunningham, C.J., Snyder, } \\
\text { K., \& Rosamond, W. }\end{array}$ & $\begin{array}{c}\text { Delivery of Automated } \\
\text { External Defibrillators (AED) } \\
\text { by Drones: Implications for } \\
\text { Emergency Cardiac Care. }\end{array}$ & 2018 & United States & Technology & Outdoor & $\begin{array}{l}\text { Emergency first } \\
\text { responders; }\end{array}$ \\
\hline
\end{tabular}




\subsection{Benefits and Costs of Drones}

All authors included in this review framed drones as a benefit to healthcare and health-related services. The most frequently discussed benefit of drones $(\mathrm{N}=20)$ was their ability to improve the response time of emergency services due to their ability to fly above roadways, water, and forested areas, and to quickly reach upper levels of high-rise buildings [4,17-19,21,22,24,25,27-31,33-35,38-41]. The second most frequently discussed benefit was the ability of drones to improve access to health services in difficult to reach areas $(\mathrm{N}=12)[4,17,22,24,25,27,28,33,36,38,39,41]$, with a specific focus on how drones can alleviate health service access issues in rural communities $[3,20,24,25,27,28,34,35]$. The third most discussed benefit was the potential for improved clinical outcomes (e.g., survival following cardiac arrest and major traumatic injuries) $(\mathrm{N}=12)$, which was often associated with the ability of drones to improve response times for emergency services [15,22,27,30,33,35-39,41,42]. Two authors noted that benefit to healthcare services would depend on financial investment from provincial partners in Canada [33], and state and private healthcare organizations in The United States [27].

Thirteen authors drew attention to different financial costs required to support drone technology use for healthcare or health-related applications. The most frequently cited financial costs included human resource expenses $(\mathrm{N}=8)$, with the need for a specially-trained drone pilot representing the most frequently identified cost associated with healthcare or health-related drone use $[17,21,24,25,27,34,37,38]$. Additional costs included the purchase price of the drone aircraft $(\mathrm{N}=5)[22,27,32,35,37]$, as well as the infrastructure costs that included drone landing stations, radar systems, drone GPS capability, air traffic control $(N=3)[27,30,35]$ and the cost to store and access data generated via drone use $(N=1)[21]$. A single author identified the burden on policy makers to formalize procedures regarding the safe use of drones that accounts for health information privacy and protection $(\mathrm{N}=1)$ [28].

\subsection{Factors Influencing Use and Performance}

Infrastructural, institutional/organizational, and environmental factors were all noted to affect the use and performance of drones and drone networks/systems. When discussing drone infrastructure, the design and usability of the drone and drone system (i.e., drone control, launch methods, drone stability with and without payloads) was the most frequently identified factor $(\mathrm{N}=20)$ to affect drone use and performance [17-22,24,25,27-29,32-34,36-39,41,42]. The number and nature of drone landing stations within a network also influenced drone use and performance. Factors such as the frequency of drone landing stations, the distance from one station to another, availability of stations within urban and rural areas, and the integration of drones into existing emergency service networks facilitated drone use $(\mathrm{N}=15)[4,17,21,24,25,28,30,33-35,37-39,42]$. The drones' flight routes $(\mathrm{N}=4)[27,28,34,38]$, the drones' payload characteristics (i.e., weight and fluid or solid composition) $(\mathrm{N}=3)[27,34,38]$, and the presence of electronic interference $(\mathrm{N}=1)$ [29] were also important influences on use and performance.

Three institutional/organizational factors were influential in the use and performance of drones. Current regulations and policies governing drone flight paths, payloads, data security, and information privacy were widely viewed as a limitation to the widespread use of drones for health interventions ( $\mathrm{N}=19)[4,18,20-22,24,25,28,29,32-39,41,42]$. Human operator factors, such as pilots' (in)ability to identify objects (e.g., targets or humans in search and rescue and emergency response interventions) through a drone-mounted camera or navigate the drone through different environments (e.g., forest, snow-covered tundra, or bodies of water) was the second-most identified institutional/organizational factor and negatively influenced drone performance $(\mathrm{N}=11)[4,17,20,22,24,25,32,33,39,40]$. When the drones were less effective than anticipated, one group of authors recommended that specially trained drone pilots should be included in emergency response teams, rather than developing pilot training to meet the needs of emergency response personnel [24,25]. Finally, a positive influence on the use and performance of drones was the establishment of partnerships between health service providers and drone companies, academic centres, or other government agencies $(N=4)[28,35,38,41]$. 
Two environmental factors influenced the use and performance of drones. First, geographic factors such as mountains, bodies of water, snow-covered land, forests, and urban areas with dense building configurations created challenges to drone use and performance $(\mathrm{N}=9)[16,22,24,25,27,32,33,36,42]$. The second environmental factor included weather conditions such as wind, rain, and snow $(\mathrm{N}=7)[24,25,27,29,34,35,38]$.

\subsection{Community Engagement and Sociocultural Context}

Several authors $(\mathrm{N}=8)$ advocated the use of community engagement strategies as key to tailoring new use of drone technologies to particular sociocultural, health system, geographic, and climatic contexts $[4,21,22,28,32-35]$. For these authors, drone flight and program success in particular settings hinged on ensuring such initiatives involved target community stakeholders. Arguments in support of community engagement echoed arguments in the literature in favour of community engagement: increasing target community understanding and buy-in, ensuring program relevance, and increasing sustainability through local control. So, for example, one team noted informing communities about the drone project through public awareness could ease apprehension towards drones $(\mathrm{N}=1)$ [33], while another argued such information sharing could increase acceptance and use of drone technology in daily life [22]. Some researchers noted the importance of culturally relevant training courses for drone use [32,35], and the need to clearly define and identify responsibilities of healthcare professionals (i.e., EMS personnel and pharmacists) in regard to drone use and adoption into practice for context-specific health-related applications $[24,25,28,34,35]$. Few researchers $(\mathrm{N}=2)$ highlighted the importance of involving entire communities in meaningful and sustained roles so that communities can take ownership of the technology and determine how to deploy, integrate, and operate drones [32,34].

Community engagement can include a wide spectrum of activities throughout the design, testing, development, integration, and evaluation stages of new technology program development. Some of the sources reviewed endorsed, but did not describe their plans or strategies for community engagement or context-tailored work. Those who translated into action endorsement of context-attentive use of drones and community-engaged design and development processes included teams working with paramedics, Inuit communities, and firefighters [21,24,25,32]. These teams who described community engagement activities worked with target community members to develop these drone projects, train target community members to use the drones, and/or design drones to ensure these corresponded to user needs $[21,24,25,32]$.

Two additional notes on the role of engagement are worth underlining from the literature. Several researchers stressed the importance of working with diverse stakeholders (e.g., medical and drone industries, insurance companies, pharmacies, retail outlets, entrepreneurs, legislative authorities, and other policy makers) to successfully integrate drones into health systems [22,28,32,34,41]. Two authors suggested that involving communities to develop drones for healthcare or health-related services that exceed current policy restrictions (e.g., flight regulations) or community capacity (e.g., technological literacy) may represent an inappropriate use of drones as such approaches would exploit community knowledge without the possibility of the community autonomously operating the drones as tested once the research is complete [32,42].

\subsection{Author-Identified Next Steps}

Researchers acknowledged the future potential of drone use for healthcare and health-related purposes $(\mathrm{N}=18)$ and identified areas for research to: (1) improve specific elements of drone technology, (2) test viability of biological samples transported by drones, (3) enhance information privacy, (4) determine the cost-effectiveness of various drones and network configurations, (5) increase understanding of human-technology interactions, and (6) explore health-system responsiveness to using drones $[4,15-17,19,21,24,25,27,29,32-38,41]$. Researchers $(\mathrm{N}=14)$ also envisioned healthcare and health-related drone services to include rapid transport of organs and biological samples for transplant and testing and improved monitoring and prediction of natural disasters that pose public 
health emergencies [3,19-21,24,27-29,32,34,35,38,39,41]. Twelve researchers advocated for future integration of drones and trained drone pilots into healthcare services [22,24,25,27,28,33,34,37-39,41,42]. Eight researchers argued that in order for meaningful advances to occur with drones in healthcare and health-related services, new policies and regulations must first be developed that reconsider the existing restrictions on drone flight and address potential information privacy issues $[4,22,24,25,28,33,34,38]$.

\section{Discussion}

This review has demonstrated that there are eight actual healthcare and health-related applications for drones currently being studied in North America, all of which are currently in pilot stage programs and have not been widely implemented nor adopted in healthcare and health-related settings. While search criteria aimed to include studies conducted in all countries in North America, only two countries-Canada and The United States-were found to have studies exploring actual applications of drones for healthcare and health-related purposes.

Studies in this sample often suggested that loosening government restrictions placed on drone use would facilitate the development of drones for healthcare and health-related applications. How such policies and regulations are or can be accounted for in the development of drone technologies was largely absent from this sample. Authors instead focused on the flight path and payload regulations that affect the implementation of their drone services. For example, current regulatory procedures in Canada and the United States may be insufficient to protect the integrity of biological samples transported on a drone as they are too restrictive on where drones are permitted to fly beyond the pilot's line of sight $[4,6,7,9,11,43]$. In contrast, one study [28] suggested that policy makers must first develop additional regulations to safeguard the privacy of patient personal and health information. In Canada, existing PIPEDA guidelines would stipulate that personal information (including health information) contained by and within drones' computing systems as well as the non-mobile computing systems operated and maintained by the drones' corporate owners would be privy to legal privacy protections afforded by the federal government. That is, for a researcher, public, or private corporation to operate a drone for healthcare purposes, it must be in compliance with PIPEDA due to the nature of the patient data the software would contain, as well as all appropriate national and regional health policies governing the protection and handling of personal health information. While such an existing policy in Canada and the United States establishes chains of information custodianship, policy makers have an opportunity to develop new or further develop existing information protection legislation to appropriately account for the technological concerns related to the remote transportation and transmission of digital information. For example, policies and regulations must address health information security along the entire data transfer pathway-including transmission of health information from drone hardware to other infrastructure and as the drone travels between points in the health service network-to delineate digital information ownership and custodianship for individuals and corporations involved, and establish parameters for drones to operate beyond the pilot's visual line of sight [44-46].

Studies in this sample focused extensively on various actors within the healthcare sector, including those involved in biomedical supply transport, emergency first responders, and telemedicine providers. While these are logical groups to target for researchers aiming to have their drone applications adopted into practice by healthcare policy and decision makers, there was limited integration of how such applications would also influence patient groups and communities. This raises the question of who and for whom the drone applications to health are being developed. Eight studies did not have an author with any form of health, medical, or health-related affiliation. Less than a third of the author groups called for working in partnership with target communities. Even fewer actually put their calls for such engagement into action. Combined, these characteristics of drones for health suggest that some may be primarily using the health context to advance the development of drone technology and markets, rather than having a primary interest in developing drones to meet a specific health need. While this may not be a problem in some scenarios, it may become problematic when individuals 
with an understanding of patient and healthcare system needs-such as system users, front line staff, and administrators - are not given an opportunity to develop expertise and autonomy in their own field. Engagement with a broader range of users may promote the development of health-related drone applications that account for a range of health and digital literacies, which may in turn support their sustained integration into healthcare services.

This sample presented limited inclusion of Indigenous and other rural and remote communities $[3,27,29,32,43]$. When Indigenous communities were included, the authors highlighted the importance of creating meaningful and sustained involvement of Indigenous community members [32]. Such relationships aimed to foster confidence-building and skills development within the Indigenous community with an end goal of transferring full control of the drone technology to the community. This approach demonstrated by Clark et al. [32] with an Indigenous community in North America is similar to studies engaging Indigenous communities in drone development elsewhere in the world $[47,48]$. Building such relationships is considered both an ethical and legal imperative to ensure appropriate ownership over the information generated by individuals within Indigenous communities and how such information may be used for the benefit of the contributing and other Indigenous communities [49].

For rural and remote communities, embracing drone technologies for healthcare service delivery may be an effective means to access healthcare services not situated in their communities [7,8], and to maintain access to services that are downsized or removed as part of healthcare system restructuring. However, rural and remote communities' insular nature and skepticism of outside interventions, which may stem from relatively low digital and health literacies, poses a challenge to wide-scale implementation of drone healthcare service delivery models [50,51]. As such, healthcare policy and decision makers, healthcare service providers, public health planners and educators, and drone system developers should partner with established rural and remote community gatekeepers, such as Indigenous band councils, agricultural organizations, rural churches, and other rural community organizations (e.g., 4-H, Lion's Club, or Optimist Club) to gain access to and consult with rural community members when developing drone services. If built on trust and meaningful, sustained engagement, these partnerships [52] may promote rural populations to engage in digital health activities to support drone developers and lead to improved health and digital literacies as a result.

Soliciting target population segments such as Indigenous and non-Indigenous rural and remote communities, or their personal data, would require drone developers to both acknowledge and, in the view of some, compensate the communities for their input [50,51]. Failure to do so would represent a form of shadow labour, wherein communities that have been historically disenfranchised are exploited for presumably free services, such as their digital footprint [53] or feedback on a drone in exchange for its use. Therefore, failure to properly acknowledge groups that contributed to the development of drones for healthcare applications may implicate the developers in legal and ethical inquiries regarding ownership of the information gained through consultations with the disenfranchised communities $[47,49,53]$.

The economic potential for drones to reduce healthcare service delivery costs for some services in rural and remote communities [54] also presents an opportunity for policy makers to improve accessibility of care while also reducing the per treatment cost to the healthcare system or patient. However, a largely unaccounted for economic factor in this sample lies in the human costs and burden of changing best practice from existing supply delivery and telemedicine systems to systems based on drones. For example, there was no discussion of the cost associated with the human resources required to develop the infrastructure to accommodate the use of drones by a healthcare organization. Additionally, the economic toll associated with reassigning or laying off healthcare workers deemed redundant due to the integration of drones was missing from this sample. Based on approaches outlined by authors who tested how trained healthcare professionals could operate drones [24,25], there may be a penchant among drone developers to have specifically trained pilots control the drones 
opposed to healthcare personnel. While such an approach may improve the operation of a drone in isolation, there was limited discussion of how a specially trained pilot would understand healthcare and emergency triage protocols or influence quality of care.

\section{Conclusions}

This review explored how drones are being studied in healthcare and health-related applications in North America. Studies predominantly focused on population segments in the medical community and paid limited attention to how patients and communities interacted with and perceived the use of drones for health-related applications. As such, how drones transported medical equipment, medications, and biological samples was a primary focus of this sample, and authors highlighted how drones may enable healthcare providers to reach individuals in difficult to reach locations. There was limited discussion of community engagement and capacity-building efforts undertaken in the development of the drones. This suggests that authors without a health-related background may be using health as the context in which to test and demonstrate their drone's technical capabilities. It also raises concerns around shadow labour during drone development as marginalized populations, such as the rural and remote communities, may be unbeknownst contributors to the development of drones. While current regulations on drone payload and flight patterns were viewed as restricting factors to advancing drone development, further legislation must create data privacy and security regulations to maintain the integrity of personal and health information stored within drones and drone networks.

Although this sample presents a number of healthcare and health-related applications for drones in North America, further research is needed to fully understand what effects their integration into healthcare services will have. Further research should engage various patient, healthcare personnel, and cultural communities in drone development and examine how such engagement influences their digital and health literacies. Doing so will ensure that as many end-user groups contribute to their design and application; enable drone developers to design the technologies in a way that meets current needs of its target populations; and gain acceptance and support from rural, remote, and Indigenous communities that are often skeptical of outside interventions. Additionally, further examinations of the costs to integrate various drone applications into existing healthcare services-including financial, human, and healthcare quality costs-are required to gain a more wholistic understanding of how adopting various drone applications will impact a community. Such research may provide healthcare policy and decision makers with the information required to appropriately integrate drones to meet the healthcare and health-related needs of their communities.

Author Contributions: Conceptualization, B.H. and L.D; methodology, B.H. and L.D.; data validation, B.H., E.N., V.J. and L.D.; formal analysis, B.H., V.J., E.N. and L.D.; investigation, B.H., V.J., E.N. and L.D.; resources, L.D. and E.N.; data curation, B.H.; writing-original draft preparation, B.H., E.N., V.J. and L.D; writing-review and editing, E.N., L.D., V.J., and B.H.; visualization, B.H.; supervision, L.D., E.N. and B.H., project administration, B.H. All authors have read and agreed to the published version of the manuscript.

Funding: This research received no external funding.

Acknowledgments: The authors would like to thank Akeela Rabley for her administrative support during data collection.

Conflicts of Interest: The authors declare no conflict of interest.

\section{References}

1. Stoakes, U. The leapfrog opportunity in the world's underserved healthcare markets. Forbes, 1 August 2015.

2. United Nations Department of Economic and Social Affiars. World Economic and Social Survey. 2018. Available online: https://www.un.org/development/desa/dpad/wp-content/uploads/sites/45/publication/ WESS2018_full_web.pdf (accessed on 13 February 2020).

3. Glauser, W. Blood-delivering drones saving lives in Africa and maybe soon in Canada. Can. Med. Assoc. J. 2018, 190, E88-E89. Available online: http://www.cmaj.ca/lookup/doi/10.1503/cmaj.109-5541 (accessed on 14 February 2020). [CrossRef] [PubMed] 
4. Carrillo-Larco, R.M.; Moscoso-Porras, M.; Taype-Rondan, A.; Ruiz-Alejos, A.; Bernabe-Ortiz, A. The use of unmanned aerial vehicles for health purposes: A systematic review of experimental studies. Glob. Health Epidemiol. Genom. 2018, 3, e13. Available online: https://www.cambridge.org/core/product/identifier/ S2054420018000118/type/journal_article (accessed on 14 February 2020). [CrossRef] [PubMed]

5. Hampson, M. Drone delivers human kidney: The organ was flown several kilometers by a drone without incurring damage. IEEE Spectr. 2019, 56, 7-9. Available online: https://ieeexplore.ieee.org/document/8594776/ (accessed on 14 February 2020). [CrossRef]

6. Lippi, G.; Mattiuzzi, C. Biological samples transportation by drones: Ready for prime time? Ann. Transl. Med. 2016, 4, 92. Available online: http://www.ncbi.nlm.nih.gov/pubmed/27047951 (accessed on 27 February 2020). [CrossRef] [PubMed]

7. Rosser, J.C.; Vignesh, V.; Terwilliger, B.A.; Parker, B.C. Surgical and Medical Applications of Drones: A Comprehensive Review. JSLS J. Soc. Laparoendosc. Surg. 2018, 22, e2018.00018. Available online: http://www.ncbi.nlm.nih.gov/pubmed/30356360 (accessed on 25 February 2020). [CrossRef] [PubMed]

8. Scott, J.E.; Scott, C.H. Drone Delivery Models for Healthcare. In Proceedings of the 50th Hawaii International Conference on System Sciences, Village, HI, USA, 4-7 January 2017; pp. 3297-3304. Available online: http://hdl.handle.net/10125/41557 (accessed on 25 February 2020).

9. Thiels, C.A.; Aho, J.M.; Zietlow, S.P.; Jenkins, D.H. Use of unmanned aerial vehicles for medical product transport. Air Med. J. 2015, 34, 104-108. [CrossRef]

10. Canadian Agency for Drugs and Technology in Health. Health Technology Update: A Newsletter on New and Emerging Health Care Technologies in Canada Rural and Remote Issue. 2018. Available online: https://www.cadth.ca/sites/default/files/pdf/htu_issue_21_aug_2018.pdf (accessed on 12 February 2020).

11. Mendez, I.; Jong, M.; Keays-White, D.; Turner, G. The use of remote presence for health care delivery in a northern Inuit community: A feasibility study. Int. J. Circ. Health 2013, 72, 21112. Available online: https://www.tandfonline.com/doi/full/10.3402/ijch.v72i0.21112 (accessed on 11 February 2020). [CrossRef]

12. Arksey, H.; O'Malley, L. Scoping studies: Towards a methodological framework. Int. J. Soc. Res. Methodol. Theory Pract. 2005, 8, 19-32. [CrossRef]

13. Hsieh, H.-F.; Shannon, S.E. Three approaches to qualitative content analysis. Qual. Health Res. 2005, 15, 1277-1288. [CrossRef]

14. QSR International. $N^{*}$ Vivo 12; QSR International: Doncaster, Australia, 2018.

15. Al-Zayer, M.; Trelligus, S.; Bhandari, J.; Dave, F.S.; Folmer, E. Exploring the use of a drone to guide blind runners. In ASSETS 2016: Proceedings of the 18th International ACM SIGACCESS Conference on Computers and Accessibility; ACM: New York, NY, USA, 2016; pp. 263-264.

16. Al-Rawabdeh, A.; Moussa, A.; Foroutan, M.; El-Sheimy, N.; Habib, A. Time series UAV image-based point clouds for landslide progression evaluation applications. Sensors 2017, 17, 2378. [CrossRef] [PubMed]

17. Dayananda, K.R.; Gomes, R.; Straub, J. An interconnected architecture for an emergency medical response unmanned aerial system. In Proceedings of the 2017 IEEE/AIAA 36th Digital Avionics Systems Conference (DASC), St. Petersburg, FL, USA, 17-21 September 2017.

18. Cohen, J. Natural disasters: Drone spy plane helps fight California fires. Science 2007, 318, 727. [CrossRef] [PubMed]

19. Dunnington, L.; Nakagawa, M. Fast and safe gas detection from underground coal fire by drone fly over. Environ. Pollut. 2017, 229, 139-145. [CrossRef] [PubMed]

20. Francisco, M. Organ delivery by 1000 drones. Nat. Biotechnol. 2016, 34, 684. [CrossRef] [PubMed]

21. Levine, J.S.; Ambrosia, V.; Brass, J.A.; Davis, R.E.; Dull, C.W.; Greenfield, P.H.; Harrison, F.W.; Killough, B.D.; Kist, E.H.; Pinto, J.P.; et al. Monitoring wildfires using an autonomous aerial system (AAS). Remote Sens. Appl. Glob. Position Syst. 2004, 5661, 104-120.

22. Balasingam, M. Drones in medicine-The rise of the machines. Int. J. Clin. Pract. 2017, 71, 2-5. [CrossRef]

23. Gardner, T. Drone-delivered health care in rural Appalachia. Clin. Adv. 2016, 19, 18-23. Available online: http://search.ebscohost.com/login.aspx?direct=true\&db=cin20\&AN=120221648\&site=ehost-live (accessed on 23 February 2020).

24. Jain, T.; Sibley, A.; Stryhn, H.; Hubloue, I. Comparison of unmanned aerial vehicle technology-assisted triage versus standard practice in triaging casualties by paramedic students in a mass-casualty incident scenario. Prehosp Disast. Med. 2018, 33, 375-380. [CrossRef] 
25. Jain, T.; Sibley, A.; Stryhn, H.; Hubloue, I. Comparison of Unmanned Aerial Vehicle Technology Versus Standard Practice in Identification of Hazards at a Mass Casualty Incident Scenario by Primary Care Paramedic Students. Disast. Med. Public Health Prep. 2018, 12, 631-634. [CrossRef]

26. Jalal, A.H.; Umasankar, Y.; Christopher, F.; Pretto, E.A.; Bhansali, S. A model for safe transport of critical patients in unmanned drones with a 'watch' style continuous anesthesia sensor. J. Electrochem. Soc. 2018, 165, B3071-B3077. [CrossRef]

27. Kim, S.J.; Lim, G.J.; Cho, J.; Côté, M.J. Drone-Aided Healthcare Services for Patients with Chronic Diseases in Rural Areas. J. Intell. Robot. Syst. Theory Appl. 2017, 88, 163-180. [CrossRef]

28. Lin, C.A.; Shah, K.; Mauntel, L.C.C.; Shah, S.A. Drone delivery of Medications: Review of the landscape and legal considerations. Am. J. Health Pharm. 2018, 75, 153-158. [CrossRef] [PubMed]

29. Van Tilburg, C. First Report of Using Portable Unmanned Aircraft Systems (Drones) for Search and Rescue. Wilderness Environ. Med. 2017, 28, 116-118. [CrossRef] [PubMed]

30. Bogle, B.; Rosamond, W.D.; Snyder, K.T.; Zègre-Hemsey, J.K. The case for drone-assisted emergency response to cardiac arrest. N. C. Med. J. 2019, 80, 204-212. [CrossRef]

31. Cardil, A.; Monedero, S.; Ramírez, J.; Silva, C.A. Assessing and reinitializing wildland fire simulations through satellite active fire data. J. Environ. Manag. 2019, 231, 996-1003. [CrossRef]

32. Clark, D.G.; Ford, J.D.; Tabish, T. What role can unmanned aerial vehicles play in emergency response in the Arctic: A case study from Canada. PLoS ONE 2018, 13, e0205299. [CrossRef]

33. Boutilier, J.J.; Brooks, S.C.; Janmohamed, A.; Byers, A.; Buick, J.E.; Zhan, C.; Schoellig, A.P.; Cheskes, S.; Morrison, L.J.; Chan, T.C. Optimizing a Drone Network to Deliver Automated External Defibrillators. Circulation 2017, 135, 2454-2465. [CrossRef]

34. Mark, D.B.; Hansen, S.M.; Starks, M.L.; Cummings, M.L. Drone-Based Automatic External Defibrillators for Sudden Death?: Do We Need More Courage or More Serenity? Circulation 2017, 135, 2466-2469. [CrossRef]

35. Zègre-Hemsey, J.K.; Bogle, B.; Cunningham, C.J.; Snyder, K.; Rosamond, W. Delivery of Automated External Defibrillators (AED) by Drones: Implications for Emergency Cardiac Care. Curr. Cardiovasc. Risk Rep. 2018, 12, 3-7. [CrossRef]

36. Amukele, T.K.; Sokoll, L.J.; Pepper, D.; Howard, D.P.; Street, J. Can unmanned aerial systems (Drones) be used for the routine transport of chemistry, hematology, and coagulation laboratory specimens? PLoS ONE 2015, 10, e0134020. [CrossRef]

37. Amukele, T.K.; Street, J.; Carroll, K.; Miller, H.; Zhang, S.X. Drone transport of microbes in blood and sputum laboratory specimens. J. Clin. Microbiol. 2016, 54, 2622-2625. [CrossRef] [PubMed]

38. Scalea, J.R.; Restaino, S.; Scassero, M.; Blankenship, G.; Bartlett, S.T.; Wereley, N. An initial investigation of unmanned aircraft systems (UAS) and real-time organ status measurement for transporting human organs. IEEE J. Transl. Eng. Health Med. 2018, 6, 1-7. [CrossRef] [PubMed]

39. Braun, J.; Gertz, S.D.; Furer, A.; Bader, T.; Frenkel, H.; Chen, J.; Glassberg, E.; Nachman, D. The promising future of drones in prehospital medical care and its application to battlefield medicine. J. Trauma Acute Care Surg. 2019, 87 (Suppl. 1), S28-S34. [CrossRef] [PubMed]

40. Homier, V.; de Champlain, F.; Nolan, M.; Fleet, R. Identification of Swimmers in Distress Using Unmanned Aerial Vehicles: Experience at the Mont-Tremblant IRONMAN Triathlon. Prehospital. Emerg. Care 2020, 24, 451-458. [CrossRef] [PubMed]

41. Scalea, J.R.; Restaino, S.; Scassero, M.; Bartlett, S.T.; Wereley, N. The final frontier? Exploring organ transportation by drone. Am. J. Transpl. 2019, 19, 962-964. [CrossRef] [PubMed]

42. Amukele, T.K.; Hernandez, J.; Snozek, C.L.; Wyatt, R.G.; Douglas, M.; Amini, R.; Street, J. Drone Transport of Chemistry and Hematology Samples over Long Distances. Am. J. Clin. Pathol. 2017, 148, 427-435. [CrossRef]

43. Canadian Agency for Drugs and Technology in Health. Focus on: Drone Applications in Health Care. 2018. Available online: https://www.cadth.ca/sites/default/files/pdf/htu_issue_21_aug_2018.pdf (accessed on 23 February 2020).

44. Kamel Boulos, M.N.; Wilson, J.T.; Clauson, K.A. Geospatial blockchain: Promises, challenges, and scenarios in health and healthcare. Int. J. Health Geogr. 2018, 17, 25. Available online: https://ij-healthgeographics. biomedcentral.com/articles/10.1186/s12942-018-0144-x (accessed on 2 April 2020). [CrossRef] [PubMed]

45. Zeadally, S.; Isaac, J.T.; Baig, Z. Security Attacks and Solutions in Electronic Health (E-health) Systems. J. Med. Syst. 2016, 40, 263. Available online: http://link.springer.com/10.1007/s10916-016-0597-z (accessed on 2 April 2020). [CrossRef] 
46. Konert, A.; Smereka, J.; Szarpak, L. The Use of Drones in Emergency Medicine: Practical and Legal Aspects. Emerg. Med. Int. 2019, 2019, 3589792. [CrossRef]

47. Cummings, A.R.; Cummings, G.R.; Hamer, E.; Moses, P.; Norman, Z.; Captain, V.; Bento, R.; Butler, K. Developing a UAV-Based Monitoring Program with Indigenous Peoples. J. Unmanned. Veh. Syst. 2017, 5, 115-125. Available online: http://www.nrcresearchpress.com/doi/10.1139/juvs-2016-0022 (accessed on 2 April 2020). [CrossRef]

48. Paneque-Gálvez, J.; Vargas-Ramírez, N.; Napoletano, B.; Cummings, A. Grassroots Innovation Using Drones for Indigenous Mapping and Monitoring. Land 2017, 6, 86. Available online: http://www.mdpi.com/2073445X/6/4/86 (accessed on 2 April 2020). [CrossRef]

49. Resnik, D.B.; Elliott, K.C. Using Drones to Study Human Beings: Ethical and Regulatory Issues. Sci. Eng. Ethics 2019, 25, 707-718. [CrossRef] [PubMed]

50. Mackert, M.; Mabry-Flynn, A.; Champlin, S.; Donovan, E.E.; Pounders, K. Health literacy and health information technology adoption: The potential for a new digital divide. J. Med. Internet. Res. 2016, 18, e264. [CrossRef] [PubMed]

51. Manganello, J.; Gerstner, G.; Pergolino, K.; Graham, Y.; Falisi, A.; Strogatz, D. The relationship of health literacy with use of digital technology for health information: Implications for public health practice. J. Public Health Manag. Pract. 2017, 23, 380-387. [CrossRef] [PubMed]

52. Kenny, A.; Farmer, J.; Dickson-Swift, V.; Hyett, N. Community participation for rural health: A review of challenges. Health Expect. 2015, 18, 1906-1917. [CrossRef]

53. Radin, J. “Digital Natives": How Medical and Indigenous Histories Matter for Big Data. Osiris 2017, 32, 43-64. Available online: https://www.journals.uchicago.edu/doi/10.1086/693853 (accessed on 12 March 2020). [CrossRef]

54. Haidari, L.A.; Brown, S.T.; Ferguson, M.; Bancroft, E.; Spiker, M.; Wilcox, A.; Ambikapathi, R.; Sampath, V.; Connor, D.L.; Lee, B.Y. The economic and operational value of using drones to transport vaccines. Vaccine 2016, 34, 4062-4067. Available online: https://linkinghub.elsevier.com/retrieve/pii/S0264410X16304352 (accessed on 12 March 2020). [CrossRef] 